\title{
The Link Between Technical Knowledge of the Youth and Their Technical Abilities: The Role of Gender
}

\author{
Ala KOVIERIENE் \\ Šiauliai University \\ Vilnius 141, LT-76001 Šiauliai, Lithuania \\ e-mail:al.ko@tf.su.lt
}

Received: June 2009

\begin{abstract}
The paper presents the part of research for determining the link between technical knowledge of Lithuanian youth and their independence in performing jobs connected with engineering. It has also been attempted to trace whether exists any difference in this respect between the groups of boys and girls. For the research sample, young people from secondary and adult secondary schools, vocational schools, business and technical colleges, as well as university students have been chosen. Tests on theoretical technical knowledge and applied technical knowledge and questionnaire "Young people and engineering" have been employed as assessment instruments. The research leads to the conclusion independence in performing technical jobs is an important in acquiring applied technical knowledge for boys, while girls are less influenced by it. Analysis of the link between theoretical technical knowledge and experience gained in this field leads to the conclusion that level of theoretical knowledge of independent girls is higher than that of independent boys.
\end{abstract}

Keywords: comprehension-knowledge in engineering, applied technical knowledge, theoretical technical knowledge, gender, independence in performing jobs connected with engineering.

\section{Introduction}

Technical knowledge is one of the key indicators of the activity of human thought. Development of science and technology causes changes of living conditions and stimulates people to adapt themselves to a new environment. Social changes require from youth socialization more knowledge, ability to perceive and process complicated information, to make right decision in time including the choice of future career. Research work of scientists from western countries is carried out according to different state - approved assessment programs (Engineering International - Education Assessment Program, The Main Educational Assessment (MEA), Essentials of WJ III Cognitive Abilities Assessment), designed to measure and disclose different psychological and educational factors. In Lithuania, educational assessment is carried out by a group of scientists (Blinstrubas, 2002; Šaparniené, 2002; Kovierienė and Merkys, 2003; Merkys et al., 2005). The problem of assessment of technical knowledge has not yet been researched. 
Assessment of technical knowledge should be based on valid and reliable methodological and psychometric tests (Anastazi and Urbina, 2001; Cooper, 2000; Merkys, 1999). Assessment of technical knowledge could be significant for those choosing a career connected with engineering and technology, for teachers of technical professions, it could be applied in vocational orientation centre, hiring the staff for production industries, etc.

Traits of comprehension-knowledge in engineering can be observed by teacher of technology or by a practical work tutor but a problem arises when it comes to confirming such presumptions by concrete theoretical and practical research.

The difference between men and woman as potential users of functions of technical objects actually exists and arouses many discussions in contemporary society. Most investigations suggests causes of stereotypes related to the socialisation process (Herr and Cramer, 1984; Brush, 1991), while other investigations relate aptitude for technology with natural (biological) peculiarities of genders (Hausman, 2002).

Stereotypical attitudes towards male and female works have established in the society. Herr and Cramer (1984) noticed that girls usually have as extensive professional intentions as the boys, but are less confident that they will be able to achieve them (Herr and Cramer, 1984). Some girls hardly give any attention to things, not related to household and "feminine" professions. They would feel guilt and shame if they resolved to turn away from roles, traditionally attributed to them. S. Berryman presents girls' thoughts on their future: they are more willing to see themselves as raising children and only a small part plans to study in college the "exact" science - mechanics (Berryman, 1985).

The links between technical knowledge of Lithuanian youth and cognitive traits was solved (Kovierienè, 2008). General amount of respondents was 475, 310 of whom were young men.

They were representatives of Technological Faculty at Siauliai University; the others were from tertiary technical schools, colleges (technical and business), main, secondary and adult secondary schools, gymnasiums, vocational schools.

\section{Instruments for Measuring the Technical Knowledge and Interest of Lithuania Youth's in Engineering}

Statistical calculations were made using Statistical Package for the Social Sciences (SPSS). Statistical data reflecting the obtained results are presented. The factor analysis was used to reduce the number of initial variables of the study and provide new scales as this analysis allows "changing the set of characteristically features by a combination of a few factors with the minimum loss of information" (Čekanavičius and Murauskas, 2002, p. 237). During the factor analysis of Principal Components model the factor loading of test item $\mathrm{L}$ of test task was made and expressed by correlation coefficient between variable and extracted factors. Values of coefficient may range from -1 to +1 . If only three variables correlate with it answering the condition $L>0.6$, then the factor statistically is suitable. Suitability of the variables for the factor analysis is determined by KMO (Kaizer-Meyer-Olkin) coefficient. The matrix is considered suitable for the factoral analysis if the value of this coefficient is closer to 1 (if $\mathrm{KMO}<0,5$ - the factor 
analysis is unacceptable). Another important indicator is the percentage of variance explained. This value indicates the percentage of variance explained by the object under study - the factor is to be interpreted if it explains at least $10 \%$ of the subject knowledge spread (Kovieriene, 2004, 2007). For better interpretation and better examples the data available is $z$-standardised, i.e., a relative zero, the meaning of which corresponds to the result average, is set. Evaluations are recoded in such a way that a high evaluation would correspond to a positive result, whereas a low evaluation - to a negative result ( $k$-means), $k$ - number of clusters. For better data representation the figures contain lines-trends which provide information on distribution of averages.

One of the selected instruments for solving the problem put forward is a test developed in Germany and adapted - the new version of test of applied technical knowledge (Lienert, 1958). All 32 tasks with optional answers reflect practical-technical problems and can be solved mentally, 6 tasks out of which failed to correspond to Lithuanian population and, therefore, were withdrawn upon the determination of negative intercorrelation $^{1}$. The following validity factors for this test have been identified: purposeful combination and meaningful supplementation ability, and logical thinking. Its objectivity, reliability, external and internal validity have been checked.

The problem of Task 18 (Fig. 1) is that the movement of each element influences the movement of another element, thus the piece-meal movement analysis strategy has been applied.

The second test applied for measurement of technical knowledge is the test on theoretical technical knowledge. This test has been created with reference to technical knowledge treated as psychometric construct concept, considering the peculiarities of test structuring and testing procedure, and additionally consulting the experts. The format of theoretical technical knowledge test is "to find true answer" (Ingekamp, 1991). Respondents should find a true answer and its number point in the square blank (Fig. 2); answers are more than lines.

\footnotetext{
${ }^{1}$ http://www.mijnwoordenboek.nl/definition/intercorrelation
}

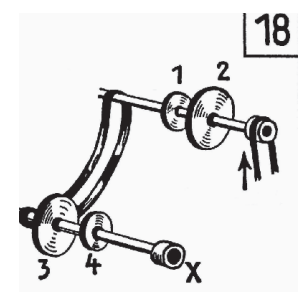

Which pulleys have to be interconnected, so that axis $\mathrm{X}$ swirls with the highest speed? Answers: $\quad \mathrm{A}-1$ and 3 $\mathrm{B}-2$ and 4 $\mathrm{C}-1$ and 4 $\mathrm{D}-2$ and 3 .

Fig. 1. Figure of Task 18 of the applied technical knowledge test.

\begin{tabular}{lll}
\hline CLUTCH & 1 & 6. The device replacing any kind of energy into the mechanical energy. \\
ENGINE & 6 & 7. The mechanism for air or gas compression.
\end{tabular}

Fig. 2. Cell of task of the theoretical technical knowledge test. 
Items are checked and analysis carried out by establishing item difficulty coefficient $P$ and item-total correlation ( $r / i t t)$. If answer have dichotomy format (yes-no) the difficulty coefficient showed a part of true answers. Results of item analysis of the test on theoretical technical knowledge are in accordance with validity standards. After multiple factor analysis (Salkind (Ed.), 2007), statements of the test on theoretical technical knowledge, in accordance with the rules of logical connection, were consolidated into five factors (Table 1), the statistical characteristics of which satisfy methodological requirements (Merkys, 1999).

On the basis of the results obtained, it is possible to confirm that tests on applied and theoretical technical knowledge are valid in respect of the assessment construct of Lithuanian teenagers' and young people's comprehension-knowledge in engineering.

The instrument for assessing non-cognitive personal traits was used in research questionnaires reflecting the level of interest of young people. The author has devised the questionnaire "Young people and engineering".

The questionnaire consists of 7 subscales in which to submit claims, requiring the approval or the quashing of the chosen notion ( $N_{\text {item }}=72$ questions):

1) toys,

2) family,

3) household appliances,

4) leisure time,

5) books, press, TV,

6) their desires and perceptions,

7) admiring people working with appliances and equipment.

Item selection of questionnaire is well grounded, accords with set forward aims and is checked by applying factor analysis as well as other statistical methods. Measurements carried out allow maintaining that factors singled out and used in research by applying the questionnaire reveal the teenagers' and young people's relation to engineering. In each subscale factor analysis, using the basic components and test the internal consistency of the determination (Reliability Analysis - Scale (Alpha)) methods, determined the factor loading of test item and item-total correlation $(r / i t t)$.

Table 1

Factor analysis of the theoretical technical knowledge test results $(\mathrm{KMO}=0.70$, percentage of variance explained $-46.59 \%$ )

\begin{tabular}{lcccc}
\hline Name of factor & $\begin{array}{l}\text { Number } \\
\text { of primary } \\
\text { variables }\end{array}$ & $\begin{array}{l}\text { Item-Total } \\
\text { Correlation, } \\
r / i t t\end{array}$ & $\begin{array}{l}\text { The factor Cronbach } \alpha \\
\text { loading of } \\
\text { test item, } L\end{array}$ \\
\hline Internal and external structure of an appliance & 6 & 0.67 & 0.861 \\
Facts of technical development history & 4 & 0.49 & 0.734 \\
Knowledge in the theory of engineering & 2 & 0.46 & 0.681 & 0.68 \\
Domestic appliances & 2 & 0.34 & 0.546 & 0.536 \\
Sequence of introducing professions and appliances & 2 & 0.31 & \\
\hline
\end{tabular}




\section{Types of Young People According to Their Ability to Do the Works Related to Technique}

Another section is aimed at identifying and characterizing statistical types, i.e., dividing the respondents into groups according to essential aspects of the research (actual technical knowledge and independence in performing job connected with engineering), k-Means cluster and discriminant analyses have been made. The cluster structure determined is presented in figures by broken lines.

It was aimed to define which groups of young people are more independent in jobs related to technique objects. For this purpose the questions related to independent work in the sphere of engineering and those, showing the level of necessary help, were chosen from sociological questionnaire "Young People and Engineering". The following questions were chosen to describe the ability to do independently technique (domestic) works:

1. When I use tools and domestic equipment that are in the house I do not need the others' help.

2. I do minor repairing works.

3. I can repair vehicles (bicycle, motorbike, car etc.).

4. I have independently made a technique-work (electric bell, plane model etc.).

5. I can drive.

The questions express directly the ability to work independently. The cluster of obtained $z$-results was made. Optimal number of clusters was chosen - statistic index form the point of view of gender is presented in Table 2. The first picture illustrates the distribution of tested young people's $z$-results form the point of view of the presented questions.

Fig. 3 is presented as broken lines represent distinguished clusters of youth's interest in engineering.

Cluster 1. To this cluster belong the respondents who did not give any positive answers to the questions related to ability to work independently in technique situations (Fig. 3). They are "not independent" young people. Not independent young people make $11.8 \%$; only $3.9 \%$ of them are the boys and $26.7 \%$ are girls. That shows that the majority of the boys have the potential of working with technique equipment. Girls' independence is influenced by stereotypic attitude that they will not be able to do the necessary technical (physical) work (Herr and Cramer, 1984; Hausman, 2002).

Table 2

Statistics of clusters of young people's independence level

\begin{tabular}{lrrrrr} 
& \multicolumn{2}{c}{ Girls } & & \multicolumn{2}{c}{ Boys } \\
\cline { 2 - 3 } \cline { 5 - 6 } & $N$ & $\%$ & & $N$ & $\%$ \\
\hline Cluster 1 & 44 & 26.7 & & 12 & 3.9 \\
Cluster 2 & 109 & 66.1 & & 82 & 26.5 \\
Cluster 3 & 12 & 7.3 & & 216 & 69.7 \\
\hline Total & 165 & 100.0 & & 12 & 3.9 \\
\hline
\end{tabular}


Cluster 2. From the presented statements "partially independent young people" underline the ability to repair a vehicle, to do independently minor repairing works and the wish to relate their future work to technique (Fig. 3). Other statements are given in the segments of the curve which are below zero line. The girls make $66.1 \%$ and the boys make $26.5 \%$ in the group of "partially independent young people".

Cluster 3. Young people who independently work with engineering objects belong to this cluster (Fig. 3). One can notice that boys (69.7\%) dominate in the group of "independent young people", girls make only $7.3 \%$. On the one hand, it is difficult for a girl to be independent in the field of technique as work with technical equipment is physically difficult, sometimes dirty; due to these reasons the girls hope the boys or men will do the mentioned functions (Herr and Cramer, 1984; Hausman, 2002).

In order to analyze the importance of independence in formation of applied and theoretical knowledge we present the diagrams (see the Figs. 3 and 4) that demonstrate an obvious connection of young peoples' level of independence and knowledge results.

Analyzing the results of Fig. 4 one can notice that the broken-lines of both boys and girls' results are similar: the broken-line of independent and partially independent young people is above the line of average and the curve of not independent young people is below the line of average. One can also see the obvious statistically important difference of $z$-results average from the point of view of gender.

Fig. 5 illustrates that the broken-line of the boys is situated higher than that of the girls. Only results of partial independent boys and girls of theoretical technical knowledge almost are equal: no marked difference has been traced between the levels of theoretical technical knowledge among the young classified as independent or partially independent.

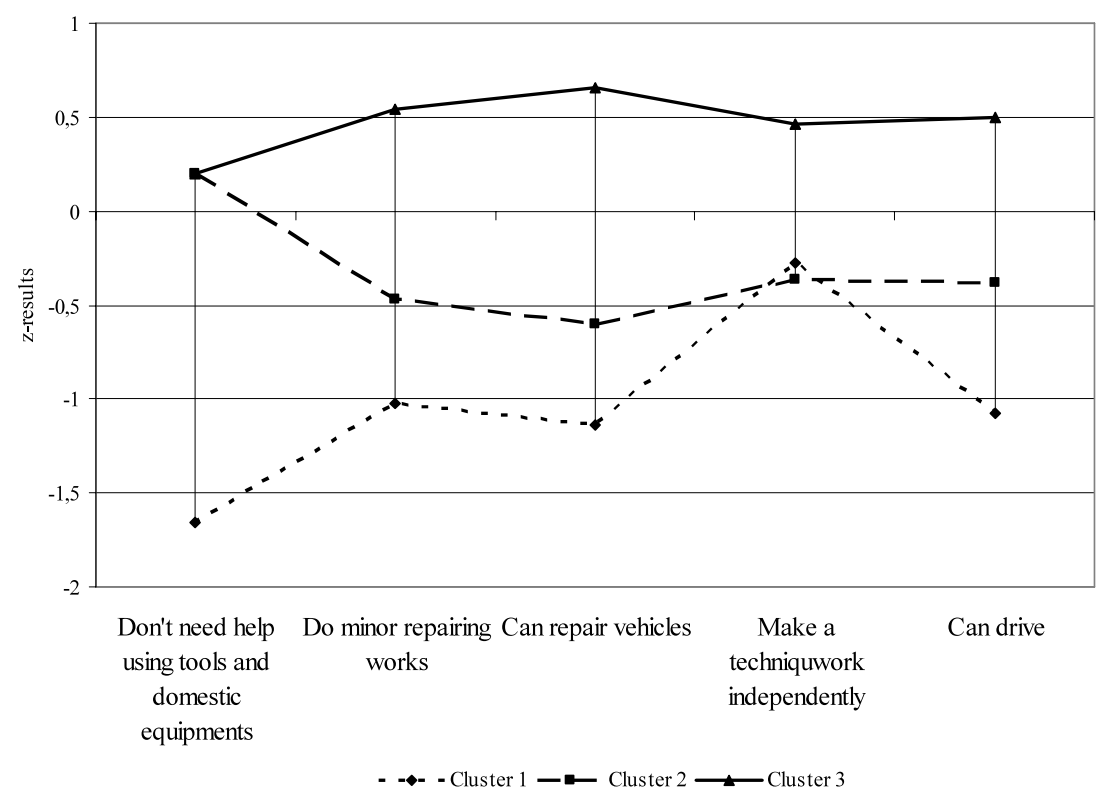

Fig. 3. The clustering of young people according to the level of their interest in engineering. 
Applied technical knowledge

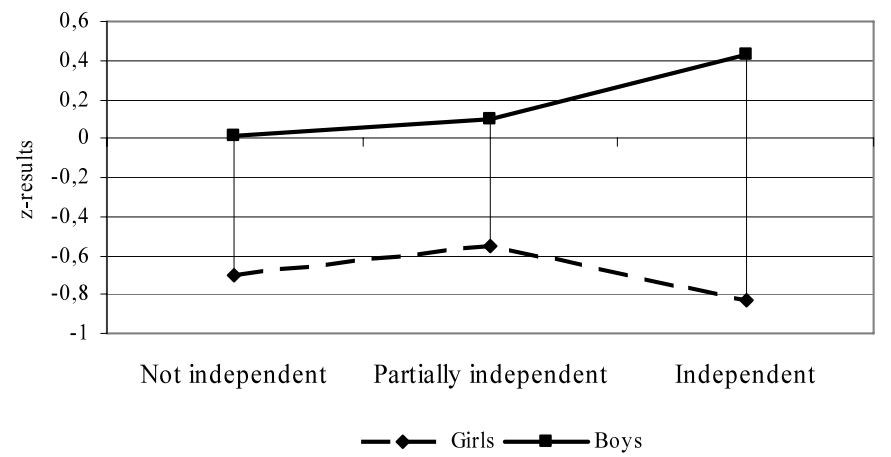

Fig. 4. The connection of $z$-results of test of applied technical knowledge with independence in the field of engineering by gender.

Theoretical technical knowledge

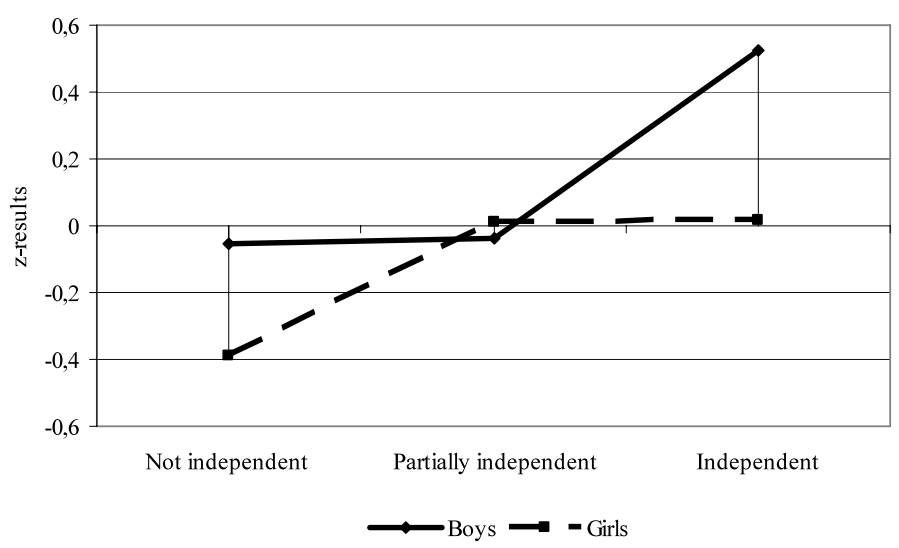

Fig. 5. The connection of $z$-results of test of theoretical technique knowledge with independence in the field of engineering by gender.

\section{Conclusions}

- The results of cluster analysis helped to define the groups of respondents characterized by independence in the field of engineering and to evaluate the number of respondents belonging to these groups from the point of view of gender.

- It has been established that applied technical knowledge connected with experience in this field of boys is considerably different from that of the girls: the higher level of independence, the better technical knowledge.

- Analysis of the link between theoretical knowledge and experience gained in this field loads to the conclusion that the level of theoretical knowledge of independent girls is higher than that of independent boys. Among the groups classified as "par- 
tially independent" and "not independent", girls have better theoretical knowledge than boys.

- It can be concluded that results of the test on young people's applied technical knowledge are closely related with their independence in the field of engineering, while theoretical technical knowledge is influenced by gained experience to a smaller extent. Nevertheless, among the group of independent girls a close interrelation between theoretical technical knowledge and applied technical knowledge has been traced.

- The training of independence is an important factor the presence of which gives an opportunity to reach good results in all spheres and higher level of technical education.

- The gender factor has a great influence on the level of the technical knowledge. This should be kept in mind while organizing the teaching process in various institutions dealing with technical education.

\section{References}

Anastazi, A., Urbina, S. (2001). Psychological Testing. Piter, Sankt-Peterburg (in Russian).

Berryman, S.G. (1985). Minorities and women in mathematics and science: Who chooses these fields and why? In: Annual Meetings of the American Association for the Advancement of Science, Los Angeles, CA, pp. 14. Blinstrubas, A. (2002). Comprehension-Knowledge of Youth and Young Adults as an Object of Educational Assessment. Summary of doctoral dissertation. Šiauliai University.

Brush, S. (1991). Women in science and engineering. American Scientist, 79, 404-419.

Cooper, K. (2000). Individual Differences. Aspect Press, Moscow (in Russian).

Čekanavičius, V., Murauskas, G. (2002). Statistics and Its Practice. II d. TEV, Vilnius (in Lithuanian ).

Hausman, P. (2002). A tale of two hormones. In: National Academy of Engineering SE Regional Meeting, Atlanta, GA.

Herr, E.L., Cramer, S.H. (1984). Career Guidance throught the Life Span. Boston, Toronto.

Ingekamp, K. (1991). Paedgogischen Diagnostik. Pedagogika, Moscow (in Russian).

Kovierienè, A. (2008). The link between technical knowledge of the youth and their technical abilities: the role of gender. Informatics in Education, 7(2), 211-219.

Kovierienè, A., Merkys, G. (2003). The comprehension-knowledge in engineering and gender: Diagnostic investigation of 19-25 aged youth of Lithuania. Pedagogika, 69, 99-105 (in Lithuanian).

Lienert, G.A. (1958). Mechanisch - Technischer - Verständnistest. Göttingen.

Merkys, G. (1999). Measurement and testing as the principle of social scences. Methodological discourse and projections. Socialiniai mokslai, 2(19), 7-22 (in Lithauanian).

Merkys, G., Zydziunaite, V., Jonusaite, S. (2005). Qualitative diagnostics of proffessional adaptation peculiarities from the aspect of social pedagogue's activity. Pedagogika, 76, 2331. www . ceeol . com.

Salkind, N. (Ed.) (2007). Encyclopedia of Measurement and Statistics. Thousand Oaks, Sage.

Šaparnienè, D. (2002). Student's Computer Literacy: Educational and Psychosocial Context of Society with Limited Resources. Summary of doctoral dissertation. Šiauliai University. 
A. Kovierienė obtained $\mathrm{PhD}$ degree in social science (educology) from Šiauliai University in 2004 and since then she has been working as an associate professor at Mechanics Engineering Department. Her main scientific interests are comprehension-knowledge in engineering. 


\title{
Sasaja tarp Lietuvos jaunuoliu techniniu žiniu ir ju savarankiškumu technikos srityje lyties aspektu
}

\author{
Ala KOVIERIENE் \\ Straipsnyje iškeltas tyrimo tikslas - nustatyti Lietuvos jaunuolių techninių žinių sąsają su jų \\ savarankiškumu technikos srityje. Tyrimo duomenys statistiškai apdoroti panaudojant modernius \\ daugiamatès statistikos metodus. Atliktas diagnostiniu instrumentu, leidžiančiu patikrinti tech- \\ nines žinias ir savarankiškumą technikos srityje, patikrinimas. Klasterinès analizès rezultatai leido \\ nustatyti respondentu grupes išsiskiriančias savarankiškumu technikos srityje ir iqvertinti šioms \\ grupėms priklausančiu tiriamuju skaičiu lyties aspektu. Nustatyta, kad jaunuoliu taikomuju ir \\ teoriniu techninių žiniu testo rezultatai priklauso nuo savarankiškumo lygio technikos srityje: \\ vaikinų ir taikomosioms, ir techninėms žinioms savarankiškumas technikos srityje daro didelę \\ ịtaką, o merginu, turinčių vidutinị savarankiškumą dirbti technikos darbus, teorinių techninių žiniu \\ rezultatai prilygsta vaikinu rezultatams. Savarankiškumo technikos srityje ugdymas yra svarbus \\ veiksnys, kuriam esant galima pasiekti gerų rezultatų visose srityse, drauge ir aukštesnị techninio \\ išprusimo lygị.
}


analysis is unacceptable). Another important indicator is the percentage of variance explained. This value indicates the percentage of variance explained by the object under study - the factor is to be interpreted if it explains at least $10 \%$ of the subject knowledge spread (Kovieriene, 2004, 2007). For better interpretation and better examples the data available is $z$-standardised, i.e., a relative zero, the meaning of which corresponds to the result average, is set. Evaluations are recoded in such a way that a high evaluation would correspond to a positive result, whereas a low evaluation - to a negative result ( $k$-means), $k$ - number of clusters. For better data representation the figures contain lines-trends which provide information on distribution of averages.

One of the selected instruments for solving the problem put forward is a test developed in Germany and adapted - the new version of test of applied technical knowledge (Lienert, 1958). All 32 tasks with optional answers reflect practical-technical problems and can be solved mentally, 6 tasks out of which failed to correspond to Lithuanian population and, therefore, were withdrawn upon the determination of negative intercorrelation $^{1}$. The following validity factors for this test have been identified: purposeful combination and meaningful supplementation ability, and logical thinking. Its objectivity, reliability, external and internal validity have been checked.

The problem of Task 18 (Fig. 1) is that the movement of each element influences the movement of another element, thus the piece-meal movement analysis strategy has been applied.

The second test applied for measurement of technical knowledge is the test on theoretical technical knowledge. This test has been created with reference to technical knowledge treated as psychometric construct concept, considering the peculiarities of test structuring and testing procedure, and additionally consulting the experts. The format of theoretical technical knowledge test is "to find true answer" (Ingekamp, 1991). Respondents should find a true answer and its number point in the square blank (Fig. 2); answers are more than lines.

\footnotetext{
${ }^{1}$ http: //www.mijnwoordenboek.nl/definition/intercorrelation
}

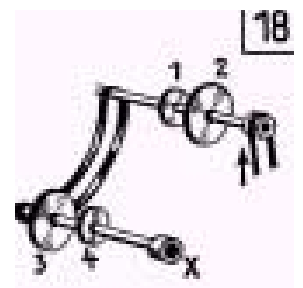

Which pulleys have to be interconnected, so that axis $\mathrm{X}$ swirls with the highest speed? Answers: $\quad \mathrm{A}-1$ and 3 $\mathrm{B}-2$ and 4 , $\mathrm{C}-1$ and 4 $\mathrm{D}-2$ and 3 .

Fig. 1. Figure of Task 18 of the applied technical knowledge test.

$\begin{array}{lll}\text { CLUTCH } & 1 & \text { 6. The device replacing any kind of energy into the mechanical energy. } \\ \text { ENGINE } & 6 & \text { 7. The mechanism for air or gas compression. }\end{array}$

Fig. 2. Cell of task of the theoretical technical knowledge test. 